\title{
DAMPAK PANDEMI COVID-19 TERHADAP AKTIVITAS PERPAJAKAN (PENGGUNAAN LAYANAN DARING, INTENSITAS LAYANAN ADMINISTRASI PAJAK, \& PERILAKU KEPATUHAN PAJAK)
}

\author{
Ryan Agatha Nanda Widiiswaa ${ }^{a}$ Hendy Prihambudi ${ }^{b}$, Ahmad Kosasih ${ }^{c}$
}

a Direktorat Jenderal Pajak. Email: ryanagatha01@gmail.com

b Direktorat Jenderal Pajak. Email: hendyprihambudi@gmail.com

c Badan Pusat Statistik. Email: ahmad_kosasih@gmail.com

\begin{abstract}
The COVID-19 pandemic, which began at the end of 2019, has globally changed so many aspects. The decline in people's consumption levels, the increase in unemployment, uncertainty for the business world, and changes in people's behaviour towards digital caused disruption for the Indonesian tax system. This study tries to look at the impact caused by the COVID-19 pandemic on taxation activities in Indonesia. Such activities will be seen from the quantity of tax service administration, the use of digital by taxpayers, and taxpayer's compliance report. The study took the period until the third quarter (September) 2020 and then it was compared with the circumstances in 2019 (January-September). This research is quantitative research by applying descriptive statistic methods as well as t-test analysis. This research is expected to provide an overview to the policy makers in understanding the changes resulting from the COVID-19 pandemic to the taxation activities in Indonesia.
\end{abstract}

Keywords: tax policy, COVID-19 Pandemic, tax compliance, digital behaviour, tax administration

\section{ABSTRAK}

Pandemi COVID-19 yang berawal di akhir tahun 2019, telah mengubah begitu banyak aspek kehidupan seluruh dunia, tidak terkecuali di Indonesia. Penurunan tingkat konsumsi masyarakat, peningkatan pengangguran, ketidakpastian bagi dunia usaha, hingga perubahan perilaku masyarakat ke arah digital menyebabkan disrupsi bagi sistem perpajakan Indonesia. Penelitian ini mencoba melihat dampak yang disebabkan oleh pandemi COVID-19 pada aktivitas perpajakan di Indonesia. Rentang waktu yang diambil adalah capaian hingga triwulan ketiga (Bulan September) tahun 2020, untuk kemudian dibandingkan dengan keadaan pada tahun 2019 (Januari-September). Penelitian ini merupakan penelitian kuantitatif dengan menerapkan metode analisis statistik deskriptif serta analisis uji beda t test. Dari penelitian ini, diharapkan dapat 
memberikan gambaran kepada pengambil kebijakan perpajakan dalam memahami perubahan yang dihasilkan akibat pandemi COVID-19 pada aktivitas perpajakan di Indonesia.

Kata kunci: kebijakan perpajakan, pandemi COVID-19, kepatuhan perpajakan, perilaku digital, administrasi pajak

\section{PENDAHULUAN}

\subsection{Latar Belakang}

Pada akhir tahun 2019, virus dengan nama ilmiah SARS-CoV-2 merebak dari kota Wuhan, Cina hingga menjadi pandemi di seluruh dunia. Penyakit ini memiliki nama resmi dari World Health Organization sebagai COVID-19. Seiring dengan merebaknya COVID-19 ke seluruh dunia, segala aspek kehidupan yang telah biasa kita jalani, dipaksa untuk mengalami perubahan.

Sebutan new normal pun menjadi hal yang sering digaungkan dalam taraf kebijakan publik pemerintah. Kehadiran new normal ini yang memberikan pembeda bagi jalannya kehidupan selama tahun 2020 melalui pembatasan kegiatan kerumunan melalui jaga jarak, cuci tangan, hingga mengenakan masker ketika beraktivitas di luar rumah (WHO, 2020).

Dari laporan yang diterbitkan oleh McKinsey \& Company (2020) disebutkan terdapat beberapa hal esensial yang bakal menandai implementasi new normal, di antaranya terdiri dari perilaku konsumen terhadap adopsi teknologi digital, perubahan kebutuhan tenaga kerja yang berkaitan dengan kemampuan digital, perubahan bentuk bisnis perusahaan agar dapat bertahan, dan ketidakjelasan tatanan situasi yang ada hingga menyebabkan pemerintah G-20 mengeluarkan paket stimulus 3 (tiga) kali lipat dari krisis finansial pada tahun 2008.

Sedangkan terkait dengan perubahan perilaku digital sendiri, disebutkan Mckinsey \& Company (2020) bahwa pengambil kebijakan pada sektor bisnis percaya bahwa transaksi secara digital memiliki peranan hingga 2 (dua) kali lipat dibandingkan masa sebelum pandemi. Penelitian terkait transformasi digital oleh Soto-Acosta (2020) menyebutkan bahwa pandemi COVID-19 mengakselerasi berbagai sektor (bisnis \& pemerintahan) pada proses bisnis operasional.

Pemanfaatan teknologi digital sendiri menjadi syarat tak terelakkan bagi keberlangsungan organisasi di tengah pandemi. Hal ini juga sejalan dengan yang disebutkan oleh A. Barua (2020) bahwa dengan berubahnya perilaku masyarakat menuju digital, sektor yang tidak dapat bertransformasi digital pada saat pandemi terjadi akan mengalami dampak paling negatif.

Begitu juga dengan sektor layanan publik, berdasarkan laporan yang diterbitkan oleh Accenture (2020) maupun OECD (2020a) disebutkan bahwa layanan publik pemerintah dituntut untuk dapat memanfaatkan teknologi digital agar pelayanan masyarakat tetap berjalan secara efektif di masa pandemi. Oleh karena itu, 
di tengah pandemi ini, pemerintah termasuk di antaranya sektor perpajakan, harus dapat memanfaatkan sarana digital dalam penyelenggaraan layanan kepada masyarakat.

Kemudian, jika ditarik perspektif kepatuhan perpajakan sendiri, disrupsi pandemi yang terjadi terhadap pelayanan tidak hanya dapat mempengaruhi jalannya pelayanan yang terjadi, tetapi juga dapat berdampak terhadap kepatuhan wajib pajak. Penelitian yang dilakukan oleh Mittone (2006) menyebutkan bahwa layanan yang buruk dari kantor pajak dapat mempengaruhi kepatuhan wajib pajak.

Indonesia menganut sistem self assessment yang berlandaskan pada mekanisme voluntary compliance (Harahap, 2004), dimana layanan yang ada dapat merefleksikan hubungan yang baik antara institusi perpajakan dengan wajib pajak memiliki peranan penting dalam kepatuhan perpajakan (Braithwaite, 2003). Tantangan yang muncul tidak hanya dari sisi bagaimana institusi perpajakan dapat menyelenggarakan layanan digital yang dapat merefleksikan perubahan perilaku masyarakat saat pandemi, tetapi juga menjaga kualitas layanan seperti saat sebelum pandemi agar tetap dapat menjaga kepatuhan wajib pajak.

Di lain sisi, dari sudut pandang ekonomi, pandemi ini telah memberikan tekanan pada pertumbuhan ekonomi. Pembatasan aktivitas masyarakat, hingga ketidakjelasan akan masa mendatang dalam kondisi pandemi menyebabkan daya konsumsi masyarakat serta ruang investasi menjadi menyempit. Hal ini diprediksi menyebabkan resesi secara global pada tahun 2020 dengan ditandai penurunan GDP secara global (World Bank, 2020).

Resesi yang diprediksi terjadi pada tahun 2020 diprediksi menjadi resesi paling besar keempat sejak tahun 1870 dengan dilandasi pada perhitungan atas penurunan aktivitas ekonomi, perdagangan internasional, penjualan retail, hingga konsumsi atas minyak. ILO sendiri dalam laporannya (2020) menambahkan bahwa kebijakan lockdown hingga pembatasan aktivitas pada tataran new normal menyebabkan banyak tenaga kerja kehilangan pekerjaan serta kehilangan jumlah jam bekerja, dan jika ditarik garis lurus dapat menyebabkan tekanan pada perekonomian.

World Bank (2020) memprediksi GDP Indonesia pada tahun 2020 akan mencapai angka pertumbuhan sebesar 0 persen atau terjadi penurunan dibandingkan proyeksi kenaikan sebesar 5,1 persen pada awal tahun. Direktur Jenderal Pajak, Suryo Utomo pada peringatan Hari Pajak 2020 menyebutkan bahwa paling tidak ada tiga dampak pandemi COVID-19 terhadap perekonomian yang pada akhirnya menyebabkan penurunan pada penerimaan pajak.

Konsumsi masyarakat yang turun, menimbulkan ketidakpastian yang berkepanjangan bagi iklim investasi serta dunia usaha dan pelemahan ekonomi yang menyebabkan harga komoditas serta aktivitas ekspor Indonesia berkurang (CNN Indonesia, 2020). Secara singkat, disrupsi yang terjadi pada dunia perekonomian memberikan tekanan terhadap capaian penerimaan pajak yang berjalan (Zhao, 2020) (Clemens \& Veuger, 2020). 
Kondisi perekonomian inilah jika dipandang dari sudut pandang perpajakan, tidak hanya mempengaruhi penerimaan pajak yang akan didapat, tetapi juga respon wajib pajak terhadap kewajiban perpajakan. Pada penelitian yang dilakukan oleh Heinemann (2010), disebutkan bahwa ketika dalam situasi krisis ekonomi, dorongan wajib pajak dalam mematuhi kewajiban perpajakan mengalami penurunan.

Situasi ini jika dipandang dari sisi wajib pajak seperti yang dikutip dalam penelitian Brondolo (2009) bahwa ketika terjadi krisis ekonomi, wajib pajak akan berpikir bahwa penegakan hukum tidak akan seketat sebelumnya. Selain itu, wajib pajak juga akan merasa bahwa selalu ada wajib pajak lain yang melakukan penghindaran lebih besar sehingga apa yang dilakukan oleh wajib pajak tersebut memiliki risiko yang lebih kecil serta lebih dapat diterima secara sosial ketika terjadi krisis ekonomi.

Dua kondisi inilah yaitu perubahan perilaku digital beserta perlambatan pada perekonomian menjadi latar belakang bagi peneliti untuk melakukan penelitian dengan melihat bagaimana perubahan aktivitas perpajakan pada saat terjadi pandemi COVID-19 tahun 2020. Perubahan aktivitas perpajakan tersebut akan ditinjau dari penggunaan sarana daring oleh wajib pajak, dari kuantitas layanan administrasi perpajakan terkait data pokok wajib pajak, serta kepatuhan pelaporan wajib pajak pada rentang waktu bulan Januari hingga bulan September tahun 2020.

Kondisi tersebut akan dibandingkan dengan kondisi pada saat tahun 2019 (Januari - September). Selain itu, belum adanya penelitian sejenis yang meninjau perubahan aktivitas wajib pajak selama pandemi berlangsung juga menjadi dasar dilakukannya penelitian ini. Penelitian ini merupakan penelitian kuantitatif dengan menerapkan metode analisis statistik deskriptif serta analisis uji beda $t$ test.

Pada penelitian ini, peneliti akan menggunakan data pada tingkatan Kantor Wilayah DJP dengan tidak mengikutkan Kantor Wilayah DJP Wajib Pajak Besar. Hasil dari penelitian ini diharapkan dapat memberikan gambaran kepada pengambil kebijakan perpajakan dalam memahami perubahan yang dihasilkan oleh pandemi COVID-19 pada aktivitas perpajakan di Indonesia.

\subsection{Kerangka Teoritis}

1.2.1 Pandemi COVID-19 \& Layanan Digital

Pandemi COVID-19 berdampak pada perubahan perilaku masyarakat dalam berbagai aspek, salah satunya adalah aspek penggunaan sarana digital dalam memenuhi kebutuhan konektivitas. Soto-Acosta (2020), menyatakan bahwa sejak Desember 2019 sampai dengan Mei 2020, penggunaan internet di seluruh dunia meningkat sampai dengan 60\% dibandingkan dengan periode sebelum adanya pandemi.

Dengan kondisi tersebut, maka masyarakat akan lebih banyak menjalankan aktivitas yang memanfaatkan teknologi digital. Begitu juga dari sisi pemerintah, 
dimana pemerintah harus dapat bersifat responsif dengan implementasi digitalisasi layanan publik pada saat pandemi (Accenture, 2020). Hal ini berlaku juga di sektor perpajakan.

Laporan yang dikeluarkan OECD (2020b) sendiri menyebutkan bahwa dalam kondisi pandemi, peranan layanan digital akan sangat krusial dengan mengurangi beban administrasi wajib pajak. Begitu juga dengan laporan yang dikeluarkan oleh UN/DESA (2020) bahwa layanan berbasis teknologi pada saat pandemi sangat krusial untuk menjamin efektivitas dari layanan publik. Pada saat terjadi pandemi COVID-19 sendiri, Direktorat Jenderal Pajak telah melakukan beberapa tindakan yang responsif melalui penyediaan layanan konsultasi secara daring melalui media whatsapp maupun email oleh masing-masing Kantor Pelayanan Pajak.

DJP sendiri juga melakukan perluasan atas layanan administrasi yang dapat diakses secara daring. Terhitung terdapat 17 layanan administrasi baru yang dapat diakses melalui menu login www.pajak.go.id. Layanan tersebut adalah e-PHTB, konfirmasi dokumen, konfirmasi NTPN, pemberitahuan memilih dikenai ketentuan umum PPh, perubahan data wajib pajak, surat keterangan PP 23/2018, fasilitas PPh Pasal 21, fasilitas pengurangan PPh Pasal 25, Surat Keterangan Bebas (SKB) PPh Pasal 22, SKB PPh Pasal 22 alat kesehatan, SKB PPh Pasal 23 alat kesehatan, pelaporan realisasi PPh 21 ditanggung pemerintah (DTP), pelaporan realisasi PPh Final UMKM DTP, pelaporan realisasi SKB PPh Pasal 22, pelaporan realisasi pengurangan PPh Pasal 25, dan pemberitahuan pelaporan SPT Tahunan menggunakan lampiran yang disederhanakan.

Pada penelitian ini sendiri, peneliti akan mencoba melihat perubahan tingkat penggunaan sarana daring bagi layanan perpajakan yang diakses oleh wajib pajak. Layanan perpajakan yang akan diteliti adalah layanan pendaftaran NPWP serta pelaporan SPT Tahunan. Pemilihan dua layanan tersebut sebagai objek yang diteliti dikarenakan dua layanan tersebut telah memiliki saluran secara daring untuk dapat digunakan wajib pajak sejak awal tahun 2019 sehingga dapat dibandingkan secara baik dengan kondisi pada saat pandemi terjadi.

Peneliti akan melihat tingkat penggunaan sarana daring oleh wajib pajak dengan melihat persentase penggunaan sarana daring yang dihasilkan dari pembagian antara jumlah penggunaan sarana daring dengan jumlah keseluruhan pengunaan atas layanan tersebut.

\subsubsection{Perlambatan pada Perekonomian \& Perpajakan}

Setiap terjadi perlambatan pada perekonomian, implikasi yang ditimbulkan menjadi tantangan bagi pengadministrasian penerimaan pajak di seluruh dunia (IMF, 2009). Laporan yang diterbitkan Brondolo (2019) menyebutkan bahwa ketika krisis ekonomi terjadi, beberapa faktor yang paling besar dalam menggerus penerimaan pajak adalah 
(1) penurunan basis pajak, (2) penurunan harga komoditas dan keuntungan dari sektor terkait, (3) diskresi pada kebijakan perpajakan, dan (4) perubahan kepatuhan wajib pajak.

Lalu, dilihat dari apa yang disebutkan oleh Johnson et al. (2010) bahwa pada saat terjadi resesi di Amerika Serikat pada tahun 2008, terjadi penurunan penerimaan pajak hingga 11 persen. Penurunan ini disebabkan oleh peningkatan tingkat pengangguran, penurunan gaji, serta penurunan aktivitas ekonomi.

Sedangkan dari konteks pandemi COVID-19 sendiri, penelitian yang dilakukan oleh Zhao (2020) dengan menggunakan konteks pada negara bagian New Englands, Amerika Serikat, dinyatakan bahwa pada tahun 2021 dampak dari pandemi COVID-19 masih akan menyerang negara bagian tersebut.

Bahkan, jika pemulihan ekonomi berjalan lambat, penerimaan pajak pada tahun 2021 diprediksi menurun hingga 20-30 persen. Dengan demikian, dapat dilihat bahwa ketika negara dihadapkan dalam posisi berhadapan dengan perlambatan perekonomian akibat pandemi COVID-19, dampak yang ditimbulkan terhadap penerimaan pajak tidak dapat dihindari.

Akan tetapi relasi antara perpajakan dengan perlambatan perekonomian tidak berhenti di situ, hal ini dikarenakan penerimaan pajak bertumpuan pada pertumbuhan ekonomi (Gupta, 2007). Bahkan, dalam penelitian yang dilakukan oleh Castro \& Camarillo (2014) disebutkan bahwa PDB (Pendapatan Domestik Bruto) perkapita merupakan aktor determinan dalam capaian penerimaan pajak. Dengan demikian, problematika yang timbul dalam kondisi perlambatan perekonomian adalah bagaimana membuat proses pemulihan ekonomi dapat berjalan dengan cepat sehingga pertumbuhan PDB dapat menjadi normal kembali.

Ditambah lagi, sifat perpajakan apabila tidak dilakukan secara hati-hati dapat menimbulkan sentiment negatif pada pertumbuhan ekonomi (Ferede \& Dahlby, 2012), terlebih ketika dunia tengah dilanda perlambatan pada perekonomian. Pada penelitian S. Barua (2020) disebutkan bahwa dalam proses pemulihan ekonomi, pajak akan memainkan peran kunci terutama untuk meningkatkan investasi serta pembuatan lapangan kerja pada sektor-sektor tertentu.

Peranan tersebut salah satunya dapat diimplementasikan melalui insentif pajak. Insentif pajak sendiri dalam perspektif kondisi pandemi COVID-19 dapat ditujukan pada ketahanan ekonomi (OECD, 2020c), termasuk untuk menunjang sektor kesehatan serta sektor yang terdampak langsung pandemi COVID-19. Hal ini didukung oleh penelitian Brondolo (2009) bahwa dalam kondisi perlambatan perekonomian, salah satu peranan utama institusi perpajakan adalah membantu pelaku usaha untuk tetap bertahan melalui krisis yang terjadi, salah satunya melalui stimulus perpajakan.

Bentuk kepedulian pemerintah melalui pemberian stimulus perpajakan dapat diartikan sebagai bantuan bagi pelaku usaha untuk bertahan selama 
perlambatan perekonomian terjadi melalui peningkatan profil institusi perpajakan. Pengalaman Yunani dalam menghadapi krisis ekonomi adalah dengan membangun profil institusi perpajakan yang baik sebagai salah satu strategi untuk menjaga kepatuhan wajib pajak (Kaplanoglou et al., 2016).

Oleh karena itu, melalui insentif perpajakan yang direncanakan dan dikelola secara efektif dan efisien, tidak hanya dapat membantu pemulihan ekonomi secara lebih cepat tetapi juga pada keberlanjutan anggaran ke depannya terutama setelah perlambatan pada perekonomian berakhir.

Direktorat Jenderal Pajak sendiri telah mengeluarkan beberapa insentif terkait dengan merespon perlambatan perekonomian yang terjadi, yaitu melalui pemberian insentif PPh Pasal 21 ditanggung pemerintah untuk penghasilan yang diterima pegawai, pembebasan dari pemungutan PPh Pasal 22 Impor, pengurangan angsuran PPh Pasal 25, restitusi PPN dipercepat, insentif PPh \& PPN untuk alat kesehatan \& pendukungnya, PPh UMKM (PP 23/2018) ditanggung pemerintah, pengurangan penghasilan bruto atas sumbangan dalam rangka penanganan COVID-19, PPh tarif 0\% untuk petugas di bidang kesehatan dalam rangka penanganan COVID-19, PPh 0\% atas persewaan tanah bangunan dalam rangka penanggulangan COVID-19, dan insentif untuk pembelian kembali saham di bursa efek.

\subsubsection{Dampak pada Kuantitas Layanan Administrasi Perpajakan}

Pandemi COVID-19 yang terjadi menyebabkan perubahan secara sosial maupun ekonomi di masyarakat (Leung et al., 2020). Pembatasan aktivitas yang harus dilakukan untuk menekan laju pertumbuhan penyebaran virus COVID-19 mengakibatkan sektor usaha secara umum tidak dapat berjalan secara normal, sehingga mengakibatkan terjadinya tekanan pada perekonomian. Menurut Young (2007), perlambatan perekonomian dapat mempengaruhi norma sosial wajib pajak terhadap kepatuhan perpajakan. Hasil penelitian tersebut juga didukung oleh Heinemann (2010) yang menyebutkan bahwa ketika terjadi perlambatan perekonomian, moral dari wajib pajak mengalami penurunan yang berdampak pada kepatuhan.

Dengan demikian, kondisi pandemi COVID-19 yang terjadi, dapat memberikan tekanan pada kepatuhan perpajakan. Pada penelitian OECD (2004) disebutkan bahwa terdapat empat pilar kepatuhan, di mana salah satu pilar pertama adalah pendaftaran. Penelitian ini sendiri ingin melihat bagaimana aktivitas wajib pajak terhadap kegiatan pendaftaran. Pada penelitian ini, aktivitas pendaftaran akan diperluas pada layanan administrasi yang terkait dengan data pokok wajib pajak.

Layanan administrasi terkait data pokok wajib pajak terdiri dari pendaftaran NPWP, penghapusan NPWP, perubahan data wajib pajak, pengukuhan pengusaha kena pajak (PKP), pembatalan penghapusan NPWP, pembatalan pencabutan PKP, dan pemindahan wajib pajak. 
Ketujuh layanan tersebut merupakan bagian dari layanan yang diatur pada PER-04/PJ/2020 tentang Petunjuk Teknis Pelaksanaan Administrasi Nomor Pokok Wajib Pajak, Sertifikat Elektronik, dan Pengukuhan Pengusaha Kena Pajak.

Peneliti akan melihat bagaimana perubahan total penggunaan layanan administrasi terkait data pokok wajib pajak pada tahun 2019 dengan kondisi pada saat pandemi terjadi dengan rentang waktu Januari hingga September.

\subsubsection{Dampak pada Kepatuhan Perpajakan}

Perlambatan pada perekonomian yang terjadi tidak hanya berdampak pada angka-angka capaian ekonomi yang ada, tetapi juga mempengaruhi perilaku masyarakat. Kepatuhan perpajakan wajib pajak didorong pada norma sosial pribadi untuk mematuhi kewajiban perpajakan (Torgler, 2007).

Pada kondisi terjadi perlambatan perekonomian, perubahan realita yang terjadi dapat mempengaruhi norma sosial wajib pajak terhadap kepatuhan perpajakan (Young, 2007). Sedangkan, pada hasil penelitian Heinemann (2010) disebutkan bahwa ketika terjadi krisis ekonomi, moral pajak dari wajib pajak mengalami penurunan sehingga mempengaruhi keberlanjutan penganggaran negara.

Oleh karena itu, dapat diambil kesimpulan, bahwa ketika terjadi perlambatan perekonomian maka dorongan wajib pajak terhadap kepatuhan perpajakan dapat mengalami disrupsi.
Dari sudut pandang yang berbeda, Brondolo (2009) menyebutkan bahwa krisis ekonomi menyebabkan wajib pajak menjadi lebih berani dalam mengambil risiko untuk melakukan ketidakpatuhan perpajakan jika dibandingkan risiko yang didapat dalam menghadapi kebangkrutan usaha.

Hal ini berlandaskan pada narasi kepatuhan pajak yang diungkapkan Allingham \& Sanmo (1972) bahwa kepatuhan perpajakan digerakkan oleh perhitungan antara risiko denda yang didapat ketika tertangkap melakukan ketidakpatuhan dengan keuntungan yang didapat ketika melakukan kepatuhan perpajakan.

Sedangkan pada perlambatan perekonomian, perhitungan yang dialami wajib pajak bertambah dengan kemungkinan kebangkrutan yang dialami. Lebih lanjut, Brondolo (2009) menyebutkan bahwa pada saat kondisi tekanan pada sektor ekonomi, wajib pajak akan berpikir bahwa penegakan hukum tidak akan seketat pada saat sebelumnya serta berprasangka bahwa selalu ada wajib pajak lain yang melakukan penghindaran lebih besar sehingga wajib pajak tersebut memiliki risiko yang lebih kecil serta pembenaran secara sosial.

Terkait dengan ketidakpatuhan yang terjadi sendiri pada saat terjadi tekanan pada perekonomian, Brondolo (2009) menyebutkan bahwa bentuk ketidakpatuhan terdiri dari (1) melakukan transaksi yang memiliki kewajiban perpajakan tetapi tanpa terdaftar di institusi perpajakan (non NPWP), (2) tidak melaporkan SPT secara tepat waktu, (3) memperkecil kewajiban 
perpajakan yang dilaporkan, atau (4) membayar pajak lebih kecil dari kewajiban yang ada.

Pada penelitian ini, peneliti mencoba melihat perubahan tingkat kepatuhan wajib pajak pada saat terjadi pandemi dari dari poin ketidakpatuhan yang mungkin terjadi pada saat terjadi tekanan pada sektor ekonomi pada laporan (Brandolo, 2009). Kepatuhan wajib pajak dalam penelitian ini, terjabar sebagai berikut.

a. Tingkat penggunaan identitas NPWP ketika melakukan pembayaran pajak.

Pada penelitian Brandolo (2009) sendiri disebutkan bahwa ketika terjadi krisis ekonomi, maka wajib pajak memiliki kecenderungan untuk melakukan transaksi yang memiliki kewajiban perpajakan tetapi tanpa terdaftar di institusi perpajakan. Pada penelitian ini sendiri, peneliti akan melihat penggunaan identitas NPWP pada pembayaran PPN atas kegiatan membangun sendiri (PER-25/PJ/2012) serta pada pembayaran pajak PPh atas pengalihan hak atas tanah dan atau bangunan (PER-18/PJ/2017).

Dikarenakan pada kedua pembayaran tersebut, wajib pajak yang belum memiliki NPWP dapat menggunakan identitas non NPWP ketika melakukan pemenuhan kewajiban perpajakannya. Peneliti sendiri akan membandingkan persentase wajib pajak yang menggunakan NPWP ketika melakukan pembayaran pajak PPN atas kegiatan membangun sendiri atau PPh atas pengalihan hak atas tanah dan atau bangunan ketika kondisi saat pandemi terjadi (Januari 2020 September 2020) dengan sebelum pandemi terjadi (Januari 2019 September 2019).

b.Tingkat ketepatan waktu pelaporan SPT Tahunan

Pada penelitian ini, peneliti akan melihat tingkat ketepatan waktu pelaporan SPT Tahunan baik wajib pajak badan maupun orang pribadi. SPT Tahunan yang ditinjau sendiri adalah untuk tahun pajak 2019 yang dilaporkan pada rentang waktu tahun 2020 (Januari - September 2020). Kemudian akan dibandingkan dengan tingkat ketepatan waktu pelaporan SPT Tahunan tahun pajak 2018 yang dilaporkan pada tahun 2019 (Januari September 2019). Batas waktu pelaporan SPT Tahunan yang digunakan sesuai dengan pasal 3 ayat (3) UU Ketentuan Umum Perpajakan Nomor 28 Tahun 2007, yaitu:

1. Batas waktu penyampaian SPT Tahunan Badan pada akhir bulan April

2. Batas waktu penyampaian SPT Tahunan Orang Pribadi pada bulan Maret.

Pada konteks SPT Tahunan Orang Pribadi tahun pajak 2019 yang dilaporkan pada tahun 2020, peneliti akan menggunakan batas waktu pelaporan pada akhir bulan April 2020 sehubungan dengan kebijakan relaksasi penyampaian SPT Tahunan Orang Pribadi pada KEP-156/PJ/2020 tentang Kebijakan Perpajakan Sehubungan Dengan Penyebaran Wabah Virus Corona 2019.

c. Tingkat ketepatan waktu pelaporan SPT Masa PPN

Penelitian ini akan melihat tingkat ketepatan waktu pelaporan SPT Masa PPN. 
Peneliti sendiri mengambil tingkat kepatuhan dari perspektif kepatuhan pelaporan SPT Masa PPN dikarenakan pada konteks pandemi sendiri, sektor PPN terlepas dari insentif perpajakan sehingga kewajiban pelaporan yang melekat pada PKP masih tetap ada.

Tingkat ketepatan waktu pelaporan yang akan diteliti diambil dari persentase wajib pajak PKP (Pengusaha Kena Pajak) yang melakukan pelaporan SPT Masa PPN tepat waktu sepanjang rentang waktu (Januari-September) dibandingkan dengan total jumlah wajib pajak PKP yang ada. Kepatuhan dari perspektif pelaporan ini dihitung dari kewajiban pelaporan SPT Masa PPN yang ada pada rentang waktu Januari hingga September, yaitu masa pajak Desember tahun sebelumnya, masa pajak Januari, Februari, Maret, April, Mei, Juni, Juli, dan Agustus. Batas waktu pelaporan SPT Masa PPN yang digunakan adalah akhir bulan berikutnya dari masa pajak tersebut sesuai dengan Pasal 10 dan 11 PMK-9/PMK.03/2018. Tetapi apabila batas penyampaian tersebut bertepat pada hari libur maka batas waktu pelaporan akan jatuh pada hari berikutnya sesuai dengan Pasal 12 ayat (1) PMK-243/PMK.03/2014.

Peneliti akan membandingkan persentase yang didapat pada tahun 2020 dengan tahun 2019. PKP yang menjadi objek penelitian adalah wajib pajak aktif yang telah menjadi PKP sejak awal tahun 2019 serta masih menjadi PKP aktif hingga bulan September 2020. Pengertian wajib pajak aktif merupakan wajib pajak yang tidak masuk dalam kategori sebagai Wajib Pajak Non Efektif seperti yang tertera pada Pasal 24 Ayat 2 PER-04/PJ/2020 tentang Petunjuk Teknis Pelaksanaan Administrasi Nomor Pokok Wajib Pajak, Sertifikat Elektronik, Dan Pengukuhan Pengusaha Kena Pajak.

Selain itu, variabel kepatuhan wajib pajak yang akan diteliti juga melihat pada empat pilar kepatuhan yang terjabar pada OECD (2004), di mana tingkat penggunaan identitas NPWP ketika melakukan pembayaran pajak merupakan kepatuhan secara pendaftaran, serta tingkat ketepatan waktu pelaporan SPT Tahunan \& SPT Masa PPN merupakan kepatuhan secara pelaporan.

Sedangkan untuk dua pilar kepatuhan lainnya yaitu penyampaian laporan secara akurat serta pembayaran pajak secara tepat waktu tidak dimasukkan dalam model penelitian ini. Pengambilan dua aspek dari empat pilar kepatuhan yang ada sendiri didasari pada rentang waktu penelitian yang dilakukan serta keterbatasan data yang tersedia. Rentang penelitian yang dilakukan pada saat terjadi pandemi membatasi peneliti untuk dapat melakukan pengujian terhadap keakuratan pelaporan yang telah dilakukan oleh wajib pajak maupun pembayaran yang dilakukan.

\subsection{Pengembangan Hipotesis}

1.3.1 Perbedaan Pengunaan Layanan Perpajakan secara Daring saat Pandemi COVID-19 
Berdasarkan penelitian Soto-Acosta (2020) disebutkan bahwa kondisi pandemi COVID-19 mengakselerasi perilaku digital masyarakat. Dari sisi pemerintah sendiri, UN/DESA (2020) menyebutkan bahwa layanan publik berbasis digital pada saat pandemi sangat krusial untuk menjamin efektivitas dari layanan publik.

Peneliti akan melihat penggunaan layanan perpajakan secara daring untuk layanan pendaftaran NPWP dan pelaporan SPT Tahunan, dikarenakan ketersediaan atas sarana daring atas kedua layanan tersebut sejak awal tahun 2019. Berangkat dari kondisi tersebut, hipotesis yang akan diuji adalah:

$\mathrm{H1}$ : Tingkat penggunaan layanan perpajakan secara daring ditinjau dari pelaporan SPT Tahunan cenderung lebih tinggi saat terjadi pandemi COVID-19

H2: Tingkat penggunaan layanan perpajakan secara daring ditinjau dari pendaftaran NPWP cenderung lebih tinggi saat terjadi pandemi COVID-19

\subsubsection{Perbedaan Tingkat Penggunaan} Layanan Administrasi Perpajakan yang Berkaitan dengan Data Pokok Wajil Pajak saat Pandemi COVID-19

Pandemi COVID-19 yang terjadi menyebabkan perubahan perilaku di masyarakat. Penerapan new normal (WHO, 2020) mengharuskan masyarakat untuk melakukan social distancing hingga pembatasan aktivitas di luar rumah (Leung et al., 2020). Sedangkan, dari perspektif pemenuhan kewajiban perpajakan sendiri Heinemann (2010) menyebutkan bahwa ketika terjadi krisis ekonomi, moral pajak dari wajib pajak untuk melakukan melaksanakan kepatuhan perpajakan mengalami penurunan.

Peneliti akan melihat perbedaan tingkat penggunaan layanan administrasi perpajakan yang berkaitan dengan data pokok wajib pajak saat pandemi COVID-19 terjadi. Hal ini selain dikarenakan data pokok wajib pajak merupakan hal yang berkaitan dengan identitas wajib pajak, dimana identitas wajib pajak merupakan pintu awal dari kepatuhan wajib pajak pada tingkat selanjutnya. Berangkat dari penjelasan di atas, hipotesis yang akan diuji adalah:

H3: Tingkat penggunaan layanan administrasi perpajakan yang berkaitan dengan data pokok wajib pajak cenderung lebih rendah saat terjadi pandemi COVID-19

\subsubsection{Perbedaan Tingkat Kepatuhan Wajib Pajak saat Pandemi COVID-19}

Seperti yang telah dijabarkan pada bagian landasan teori bahwa Pandemi COVID-19 memberikan perubahan perilaku masyarakat ke arah digital serta tekanan pada sektor ekonomi dikarenakan pembatasan aktivitas ekonomi dan faktor kesehatan pada masa pandemi (McKibbin \& Fernando, 2020). Dari dampak tersebut, peneliti melihat bahwa ketika terjadi tekanan pada sektor perekonomian, maka hal tersebut dapat berdampak secara negatif 
juga terhadap kepatuhan perpajakan wajib pajak. Belum lagi perubahan tingkah laku masyarakat ke arah digital, yang memaksa institusi perpajakan harus dapat bersifat responsif terhadap perubahan yang terjadi.

DJP sendiri telah melaksanakan beberapa kebijakan untuk merespon dampak yang disebabkan oleh pandemi COVID-19, mulai dari pemberian insentif perpajakan pada sektor yang terdampak, pembukaan layanan konsultasi secara digital, hingga perluasan layanan administrasi yang dapat diakses secara daring. Berangkat dari penjelasan di atas, hipotesis yang akan diuji adalah:

H4: Tingkat kepatuhan perpajakan ditinjau dari tingkat penggunaan identitas ber-NPWP ketika melakukan pembayaran pajak cenderung lebih rendah setelah saat pandemi COVID-19.

H5: Tingkat kepatuhan perpajakan melalui tingkat ketepatan waktu pelaporan SPT Tahunan cenderung lebih rendah saat terjadi pandemi COVID-19.

H6: Tingkat kepatuhan perpajakan melalui tingkat ketepatan waktu pelaporan SPT Masa PPN cenderung lebih rendah saat terjadi pandemi COVID-19.

\section{METODOLOGI PENELITIAN}

Penelitian ini merupakan penelitian secara kuantitatif dengan uji beda paired sample t-test untuk mengetahui apakah ada perbedaan keadaan variabel. Uji beda paired sample t-test digunakan dalam penelitian ini karena data akan dikelompokkan dalam dua kelompok yang saling berhubungan, yaitu kelompok data sebelum terjadi pandemi COVID-19 pada rentang waktu (Januari - September 2019) dengan kelompok data saat terjadinya pandemi COVID-19 pada rentang waktu (Januari September 2020). Variabel yang akan diujikan pada penelitian ini, adalah:

a. Tingkat penggunaan layanan perpajakan secara daring ditinjau dari pelaporan SPT Tahunan

b. Tingkat penggunaan layanan perpajakan secara daring ditinjau dari pendaftaran NPWP

c. Tingkat penggunaan layanan administrasi perpajakan yang berkaitan dengan data pokok wajib pajak

d. Tingkat kepatuhan perpajakan ditinjau dari tingkat penggunaan identitas ber-NPWP ketika melakukan pembayaran perpajakan

e. Tingkat kepatuhan perpajakan melalui tingkat ketepatan waktu pelaporan SPT Tahunan

f. Tingkat kepatuhan perpajakan melalui tingkat ketepatan waktu pelaporan SPT Masa PPN

Penelitian ini menggunakan sumber data sekunder secara kuantitatif. Populasi pada penelitian adalah seluruh Kantor Wilayah DJP se-Indonesia, dengan mengeleminasi Kantor Wilayah DJP Wajib Pajak Besar. Eliminasi Kantor Wilayah DJP Wajib Pajak Besar dikarenakan wajib pajak pada kantor wilayah tersebut berisikan wajib pajak-wajib pajak dengan tingkat pembayaran pajak terbesar di Indonesia serta jumlah wajib pajak pada kantor wilayah tersebut berjumlah lebih sedikit 
dibandingkan dengan kantor wilayah lainnya.

Pengeliminasian ini diharapkan dapat membuat data yang akan diteliti berdistribusi normal. Maka, diperoleh 33 kantor wilayah yang menjadi objek penelitian pada penelitian ini. Dengan mempertimbangkan keterbatasan data serta jangka waktu penelitian yang ada, peneliti mengambil objek penelitian pada tingkatan data kantor wilayah. Tetapi data yang digunakan sendiri merupakan agregasi pula dari data seluruh wajib pajak yang terdaftar pada Kantor Pelayanan Pajak yang tercakup dalam Kantor Wilayah DJP tersebut.

Dengan adanya agregasi bertingkat tersebut, maka hasil pengolahan data di tingkat Kantor Wilayah secara tidak langung akan memberikan gambaran yang baik dari perilaku pada tingkat wajib pajak. Pengumpulan data pada penelitian ini dilakukan dengan metode penelitian arsip. Data pada penelitian ini diperoleh atas data historis dari sumber yang relevan yaitu basis data Direktorat Jenderal Pajak. Pengolahan data tersebut adalah dengan langkah pada Tabel 1 berikut.

Tabel 1 Pengolahan Data

\begin{tabular}{|c|c|}
\hline Variabel & Keterangan \\
\hline $\begin{array}{l}\text { Tingkat penggunaan layanan } \\
\text { perpajakan secara daring } \\
\text { ditinjau dari pelaporan SPT } \\
\text { Tahunan }\end{array}$ & $=\frac{\text { Jumlah SPT Tahunan yang dilaporkan melalui sarana daring }}{\text { Jumlah seluruh SP Tahunan yang dilaporkan }}$ \\
\hline $\begin{array}{l}\text { Tingkat penggunaan layanan } \\
\text { perpajakan secara daring } \\
\text { ditinjau dari pendaftaran } \\
\text { NPWP }\end{array}$ & $=\frac{\text { Jumlah Permohonan Pendaftaran NPWP yang dilakukan melalui sarana daring }}{\text { Jumlah seluruh Permohonan Pendaftaran NPWP }}$ \\
\hline $\begin{array}{l}\text { Tingkat penggunaan layanan } \\
\text { administrasi perpajakan yang } \\
\text { berkaitan dengan data pokok } \\
\text { wajib pajak }\end{array}$ & $\begin{array}{l}\qquad \text { Jumlah layanan yang digunakan oleh wajib pajak } \\
\text { Layanan tersebut terdiri dari: } \\
\text { - Pendaftaran NPWP } \\
\text { - Penghapusan NPWP } \\
\text { - Perubahan Data Wajib Pajak } \\
\text { - Pengukuhan Pengusaha Kena Pajak (PKP) } \\
\text { - Pembatalan Penghapusan NPWP } \\
\text { - Pembatalan Pencabutan PKP } \\
\text { - Pemindahan Wajib Pajak }\end{array}$ \\
\hline $\begin{array}{l}\text { Tingkat } r \text { kepatuhan } \\
\text { perpajakan ditinjau dari } \\
\text { tingkat penggunaan } \\
\text { identitas berNPWP ketika } \\
\text { melakukan pembayaran } \\
\text { pajak }\end{array}$ & $\begin{array}{l}\qquad \frac{\text { Jumlah Pembayaran Pajak yang menggumakan NPWP }}{\text { Jumlah seluruh Pembayaran Pajak }} \\
\text { Pembayaran pajak yang dimaksud adalah: } \\
\text { a. Pembayaran PPh atas Pengalihan Hak atas Tanah dan/ Bangunan, dan } \\
\text { b. Pembayaran PPN Kegiatan Membangun Sendiri }\end{array}$ \\
\hline $\begin{array}{l}\text { Tingkat kepatuhan } \\
\text { perpajakan melalui tingkat } \\
\text { ketepatan waktu pelaporan } \\
\text { SPT Tahunan }\end{array}$ & $=\frac{\text { Jumlah SPT Tahuman yang dilaporkan secara tepat waktu }}{\text { Jumlah seluruh SPT Tahuman yang dilaporkan }}$ \\
\hline $\begin{array}{l}\text { Tingkat kepatuhan } \\
\text { perpajakan melalui tingkat } \\
\text { ketepatan waktu pelaporan } \\
\text { SPT Masa PPN }\end{array}$ & $\begin{array}{l}\qquad=\frac{\text { Jumlah PKP yang melakukan pelaporan SPT Masa PPN secara tepat waktu }}{\text { Jumlah seluruh PKP }} \\
\text { PKP yang dimaksud disni sendiri adalah Wajib Pajak aktif yang telah menjadi PKP } \\
\text { sejak awal tahun } 2019 \text { serta masih menjadi PKP aktif hingga bulan September } \\
\text { 2020. }\end{array}$ \\
\hline
\end{tabular}


Peneliti akan melakukan analisis dengan menggunakan analisis deksriptif untuk mengetahui gambaran data dan pengujian paired sample t-test

\section{HASIL DAN PEMBAHASAN}

\subsection{Pengujian Deskriptif, Validitas, dan Reliabilitas}

Pengujian dalam penelitian ini dimulai untuk mengetahui perbedaan data akbibat pandemi. Pengolahan dilakukan dengan menggunakan SPSS versi 25 dan Microsoft Excel.

Tabel 2 Uji Statistik Deskriptif

\begin{tabular}{|c|c|c|c|c|c|c|}
\hline \multicolumn{2}{|c|}{ Variabel } & $\mathbf{N}$ & Minimum & Maximum & Mean & $\begin{array}{c}\text { Std. } \\
\text { Deviation }\end{array}$ \\
\hline \multirow{2}{*}{$\begin{array}{l}\text { Tingkat penggunaan } \\
\text { layanan perpajakan } \\
\text { secara daring ditinjau } \\
\text { dari pelaporan SPT } \\
\text { Tahunan }\end{array}$} & $\begin{array}{l}\text { Sebelum Pandemi } \\
\text { COVID-19 }\end{array}$ & 33 & 0,88 & 1 & 0,9307 & 0,0311 \\
\hline & $\begin{array}{c}\text { Saat Pandemi COVID- } \\
19\end{array}$ & 33 & 0,9 & 1 & 0,9544 & 0,02232 \\
\hline \multirow{2}{*}{$\begin{array}{l}\text { Tingkat penggunaan } \\
\text { layanan perpajakan } \\
\text { secara daring ditinjau } \\
\text { dari pendaftaran NPWP }\end{array}$} & $\begin{array}{l}\text { Sebelum Pandemi } \\
\text { COVID-19 }\end{array}$ & 33 & 0,05 & 0,36 & 0,2157 & 0,06766 \\
\hline & $\begin{array}{c}\text { Saat Pandemi COVID- } \\
19\end{array}$ & 33 & 0 & 0,56 & 0,3983 & 0,11727 \\
\hline \multirow{2}{*}{$\begin{array}{l}\text { Tingkat penggunaan } \\
\text { layanan administrasi } \\
\text { perpajakan yang } \\
\text { berkaitan dengan data } \\
\text { pokok wajib pajak }\end{array}$} & $\begin{array}{c}\text { Sebelum Pandemi } \\
\text { COVID-19 }\end{array}$ & 33 & 10.544 & 700.996 & 227.237 & $151.056,3$ \\
\hline & $\begin{array}{c}\text { Saat Pandemi COVID- } \\
19\end{array}$ & 33 & 4.604 & 372.580 & 151.284 & $88.245,4$ \\
\hline \multirow{2}{*}{$\begin{array}{l}\text { Tingkat kepatuhan } \\
\text { perpajakan ditinjau dari } \\
\text { tingkat penggunaan } \\
\text { identitas berNPWP } \\
\text { ketika melakukan } \\
\text { pembayaran } \\
\text { perpajakan }\end{array}$} & $\begin{array}{l}\text { Sebelum Pandemi } \\
\text { COVID-19 }\end{array}$ & 33 & 0,3 & 1 & 0,7828 & 0,1806 \\
\hline & $\begin{array}{c}\text { Saat Pandemi COVID- } \\
19\end{array}$ & 33 & 0,31 & 0,99 & 0,7561 & 0,18999 \\
\hline \multirow{2}{*}{$\begin{array}{l}\text { Tingkat kepatuhan } \\
\text { perpajakan melalui } \\
\text { tingkat ketepatan } \\
\text { waktu pelaporan SPT } \\
\text { Tahunan }\end{array}$} & $\begin{array}{l}\text { Sebelum Pandemi } \\
\text { COVID-19 }\end{array}$ & 33 & 0,81 & 0,95 & 0,9166 & 0,02712 \\
\hline & $\begin{array}{c}\text { Saat Pandemi COVID- } \\
19\end{array}$ & 33 & 0,7 & 0,94 & 0,8832 & 0,05146 \\
\hline \multirow{2}{*}{$\begin{array}{l}\text { Tingkat kepatuhan } \\
\text { perpajakan melalui } \\
\text { tingkat ketepatan } \\
\text { waktu pelaporan SPT } \\
\text { Masa PPN }\end{array}$} & $\begin{array}{l}\text { Sebelum Pandemi } \\
\text { COVID-19 }\end{array}$ & 33 & 0,15 & 0,74 & 0,4231 & 0,12789 \\
\hline & $\begin{array}{c}\text { Saat Pandemi COVID- } \\
19\end{array}$ & 33 & 0,13 & 0,59 & 0,3546 & 0,10431 \\
\hline
\end{tabular}

Berdasarkan Tabel 2, semua variabel yang diuji pada penelitian ini memiliki nilai rata-rata lebih besar dari nilai dengan pengujian deksriptif yang memberikan gambaran atau deskripsi atau deskripsi atas data yang akan digunakan dalam penelitian ini, dengan hasil sebagai berikut. 
lebih besar dari nilai standar deviasinya mengidentifikasikan bahwa standar eror dari variabel tersebut kecil dan pergerakannya tidak fluktuaktif (Ghazali, 2006).

Selanjutnya akan dilakukan pengujian normalitas atas data yang ada. Berdasarkan Central Limit Theorm (CLT) jika jumlah sampel penelitian lebih besar dari 30 maka di asumsikan bahwa data dalam penelitian telah terdistribusi dengan normal (Gujarati, 2003). Dengan demikian, dapat dikatakan bahwa data yang ada dalam penelitian ini berdistribusi normal.

Berikut akan dilakukan pengujian pengujian paired sample T-Test untuk melihat signifikansi perbedaan tiap pasangan variabel yang diuji. Pengujian hipotesis sendiri dilakukan dengan melihat nilai $\Delta$ mean dan nilai signifikansi yang ada. $\Delta$ mean menunjukkan perubahan yang terjadi antara nilai rata-rata yang didapat saat terjadi pandemi dengan sebelum terjadi pandemi. Sehingga $\Delta$ mean bernilai positif menunjukkan terjadi kenaikan, sedangkan $\Delta$ mean bernilai negatif menunjukkan terjadi penurunan. Signifikansi digunakan untuk menentukan apakah perbedaan yang ditimbulkan signifikan, dengan melihat apabila nilai signifikansi di bawah 0,05.

Tabel 3 Paired Sample T-Test

\begin{tabular}{|c|c|c|c|c|c|c|c|}
\hline \multirow{2}{*}{\multicolumn{2}{|c|}{ Hipotesis }} & \multicolumn{3}{|c|}{ Paired Differences } & \multirow[b]{2}{*}{$t$} & \multirow[b]{2}{*}{$d f$} & \multirow[b]{2}{*}{ Sig. } \\
\hline & & $\Delta$ Mean & $\begin{array}{c}\text { Std. } \\
\text { Deviation }\end{array}$ & $\begin{array}{c}\text { Std. Error } \\
\text { Mean }\end{array}$ & & & \\
\hline $\mathrm{H}_{1}$ & $\begin{array}{l}\text { Tingkat penggunaan layanan } \\
\text { perpajakan secara daring ditinjau dari } \\
\text { pelaporan SPT Tahunan (Saat - sebelum } \\
\text { Pandemi COVID-19) }\end{array}$ & 0,02 & 0,02 & 0,00 & 8,67 & 32 & 0,0 \\
\hline $\mathrm{H}_{2}$ & $\begin{array}{l}\text { Tingkat penggunaan layanan } \\
\text { perpajakan secara daring ditinjau dari } \\
\text { pendaftaran NPWP (Saat - sebelum } \\
\text { Pandemi COVID-19) }\end{array}$ & 0,18 & 0,10 & 0,02 & $\begin{array}{c}10,7 \\
8\end{array}$ & 32 & 0,0 \\
\hline $\mathrm{H}_{3}$ & $\begin{array}{l}\text { Tingkat penggunaan layanan } \\
\text { administrasi perpajakan yang berkaitan } \\
\text { dengan data pokok wajib pajak (Saat - } \\
\text { sebelum Pandemi COVID-19) }\end{array}$ & $\begin{array}{c}- \\
75.953,5\end{array}$ & 85.998 & 14.970 & $-5,07$ & 32 & 0,0 \\
\hline $\mathrm{H}_{4}$ & $\begin{array}{l}\text { Tingkat kepatuhan perpajakan ditinjau } \\
\text { dari tingkat penggunaan identitas } \\
\text { berNPWP ketika melakukan } \\
\text { pembayaran perpajakan (Saat - } \\
\text { sebelum Pandemi COVID-19) }\end{array}$ & $-0,03$ & 0,04 & 0,01 & $-3,46$ & 32 & 0,0 \\
\hline $\mathrm{H}_{5}$ & $\begin{array}{l}\text { Tingkat kepatuhan perpajakan melalui } \\
\text { tingkat ketepatan waktu pelaporan SPT } \\
\text { Tahunan (Saat - sebelum Pandemi } \\
\text { COVID-19) }\end{array}$ & $-0,03$ & 0,04 & 0,01 & $-4,30$ & 32 & 0,0 \\
\hline $\mathrm{H}_{6}$ & $\begin{array}{l}\text { Tingkat kepatuhan perpajakan melalui } \\
\text { tingkat ketepatan waktu pelaporan SPT } \\
\text { Masa PPN (Saat - sebelum Pandemi } \\
\text { COVID-19) }\end{array}$ & $-0,07$ & 0,03 & 0,01 & $-13,1$ & 32 & 0,0 \\
\hline
\end{tabular}


Dari tabel di atas dapat diketahui bahwa dari perubahan mean serta signifikasi, didapati hipotesis pertama \& kedua dapat diterima bahwa tingkat penggunaan layanan perpajakan secara daring ditinjau dari pelaporan SPT Tahunan maupun bahwa tingkat penggunaan layanan perpajakan secara daring ditinjau dari pendaftaran NPWP cenderung terjadi kenaikan dilihat dari perbedaan mean yang menunjukkan angka positif serta tingkat signifikansi dibawah 0,05.

Sedangkan untuk hipotesis ketiga dapat diterima bahwa tingkat penggunaan layanan administrasi perpajakan yang berkaitan dengan data pokok wajib pajak cenderung terjadi penurunan dilihat dari perbedaan mean yang menunjukkan angka negatif serta tingkat signifikansi di bawah 0,05.

Untuk hipotesis keempat, kelima serta keenam dapat ditolak bahwa untuk tingkat kepatuhan perpajakan ditinjau dari tingkat penggunaan identitas ber-NPWP ketika melakukan pembayaran perpajakan, tingkat kepatuhan perpajakan melalui tingkat ketepatan waktu pelaporan SPT Masa PPN mengalami penurunan dilihat dari perbedaan mean yang menunjukkan angka negatif serta tingkat signifikansi dibawah 0,05.

Dari perbandingan nilai absolut uji statistik $t$ yang menggambarkan perbedaan rata-rata antara data sebelum dan sesudah pandemi, nilai absolut uji statistik t dari layanan perpajakan secara daring pada pendaftaran NPWP lebih besar dibandingkan pada pelaporan SPT Tahunan. Sehingga dapat disimpulkan bahwa peningkatan layanan perpajakan secara daring pada pendaftaran NPWP memiliki perubahan yang lebih besar dibandingkan pada pelaporan SPT Tahunan. Sedangkan untuk tingkat kepatuhan sendiri, dapat dilihat bahwa penurunan terbesar terdapat pada pelaporan SPT Masa PPN serta terendah pada penggunaan identitas ber-NPWP ketika melakukan pembayaran perpajakan.

Tabel 4 Paired Sample T-Test SPT Tahunan

\begin{tabular}{|c|c|c|c|c|c|c|}
\hline \multirow[b]{2}{*}{ Perubahan SPT Tahunan } & \multicolumn{3}{|c|}{ Paired Differences } & \multirow[b]{2}{*}{$\boldsymbol{t}$} & \multirow[b]{2}{*}{$d f$} & \multirow[b]{2}{*}{ Sig } \\
\hline & $\Delta$ Mean & $\begin{array}{c}\text { Std. } \\
\text { Deviation }\end{array}$ & $\begin{array}{l}\text { Std. Error } \\
\text { Mean }\end{array}$ & & & \\
\hline $\begin{array}{l}\text { Tingkat kepatuhan perpajakan } \\
\text { melalui tingkat ketepatan waktu } \\
\text { pelaporan SPT Tahunan Badan } \\
\text { (Saat - sebelum Pandemi COVID- } \\
19\end{array}$ & $-0,041$ & 0,031 & 0,005 & $-7,59$ & 32 & 0,0 \\
\hline $\begin{array}{l}\text { Tingkat kepatuhan perpajakan } \\
\text { melalui tingkat ketepatan waktu } \\
\text { pelaporan SPT Tahunan Orang } \\
\text { Pribadi (Saat - sebelum Pandemi } \\
\text { COVID-19 }\end{array}$ & $-0,032$ & 0,048 & 0,008 & $-3,92$ & 32 & 0,0 \\
\hline
\end{tabular}


Peneliti juga mencoba mendetailkan perubahan yang terjadi pada tingkat ketepatan waktu pelaporan SPT Tahunan dengan membagi SPT Tahunan Badan serta Orang Pribadi. Dari tabel di atas dapat dilihat melalui nilai t, dimana perubahan tingkat kepatuhan pelaporan tepat waktu pada SPT Badan mengalami penurunan lebih tinggi daripada SPT Tahunan Orang Pribadi saat terjadi pandemi COVID-19.

\section{KESIMPULAN}

Melalui hasil dari penelitian ini dapat dilihat bahwa pada saat terjadi pandemi COVID-19, perilaku wajib pajak terdorong untuk lebih menggunakan sarana daring dalam menggunakan layanan perpajakan. Selain itu, temuan lain pada penelitian ini menyebutkan bahwa terjadi penurunan layanan administrasi perpajakan yang berkaitan dengan data pokok wajib pajak. Penurunan ini dapat dipahami bahwa pandemi COVID-19 memberikan tekanan pada aktivitas perekonomian masyarakat (Mckibbin \& Fernando, 2020).

Melalui hipotesis 4, 5, \& 6 dapat dilihat bahwa tingkat kepatuhan perpajakan terjadi penurunan pada saat terjadi pandemi COVID-19. Pada tingkat kepatuhan perpajakan melalui tingkat ketepatan waktu pelaporan SPT Tahunan, jika dilihat secara lebih detail dapat diketahui bahwa penurunan tingkat kepatuhan perpajakan pada wajib pajak badan lebih besar daripada wajib pajak orang pribadi. Perbedaan ini dapat dilihat sebagai dampak dari kebijakan relaksasi pelaporan SPT Tahunan wajib pajak orang pribadi pada KEP-156/PJ/2020 tentang Kebijakan Perpajakan Sehubungan Dengan Penyebaran Wabah Virus Corona 2019.

Penurunan kepatuhan perpajakan ini dapat dilihat dari relasi kondisi perekonomian, dimana pada saat terjadi perlambatan perekonomian maka hal tersebut dapat mempengaruhi dorongan wajib pajak untuk melakukan kepatuhan terhadap kewajiban perpajakannya (Heinemann, 2010) (Brondolo, 2009). DJP sendiri telah melakukan beberapa terobosan selama terjadi pandemi COVID-19, mulai dari perluasan layanan administrasi perpajakan yang dapat diakses secara daring, pemberian insentif pajak dalam rangka pemulihan ekonomi nasional, hingga pengembangan layanan digital perpajakan kedepannya melalui program 3C (Click, Call, \& Counter).

Hal ini sejalan dengan apa yang diutarakan pada Kaplanoglou et al. (2016) bahwa membangun profil institusi perpajakan yang baik dan responsif terhadap kondisi yang ada sangat berdampak pada pengelolaan kepatuhan perpajakan secara berkelanjutan di masa-masa setelah kondisi perekonomian kembali normal.

\section{IMPLIKASI DAN KETERBATASAN}

Keterbatasan penelitian pada rentang waktu penelitian yang diambil maupun aspek pada empat pilar kepatuhan sesuai OECD (2004) yang belum dapat tercakup semua, dapat menjadi acuan dalam penelitian selanjutnya, sehingga penelitian selanjutnya dapat memberikan gambar secara holistik 
atas pergerakan perilaku wajib pajak khususnya terkait kepatuhan perpajakan. Perluasan atas rentang waktu penelitian serta melakukan pengamatan relasi atas pergerakan tingkat kepatuhan yang ada dengan pergerakan tingkat penerimaan pajak selama pandemi COVID-19 terjadi juga dapat dilakukan untuk memperdalam penelitian yang ada.

\section{DAFTAR PUSTAKA}

[1] Accenture. (2020). Public services for a new era. Accenture.

https://www.accenture.com/_acnmedia/PDF-13 1/Accenture-Public-Service-New-Era-UK-Final. pdf

[2] Allingham, M. G., \& Sandmo, A. (1972). Income tax evasion: A theoretical analysis. Journal of Public Economics, 1, 323-338. https://doi.org/10.1016/0047-2727(72)90010-2

[3] Barua, A. (2020). Economic impact of epidemics and pandemics in Asia since 2000: COVID-19 will likely be harsher than others. Deloitte Insights

[4] Barua, S. (2020). Understanding coronanomics: The economic implications of the coronavirus (COVID-19) Pandemic. SSRN. http://dx.doi.org/10.2139/ssrn.3566477

[5] Braithwaite, V. (2003). Dancing with tax authorities: Motivational postures and non-compliant actions. In V. Braithwaite, Taxing Democracy: Understanding Tax Avoidance and Evasion, 1st (pp. 15-39). Ashgate Publishing Ltd, Aldershot, UK

[6] Brondolo, J. (2009). Collecting taxes during an economic crisis: Challenges and policy options. International Monetary Fund Staff Position Note, 2009/017, International Monetary Fund

[7] Castro, G. Á., \& Camarillo, D. B. R. (2014). Determinants of tax revenue in OECD countries over the period 2001-2011. Contaduria y Administracion, 59(3), 35-59. https://doi.org/10.1016/S0186-1042(14)71265-3

[8] Clemens, J., \& Veuger, S. (2020). Implications of the COVID-19 pandemic for state government tax revenues. National Tax Journal, 73(3), 619-644.

https://doi.org/10.17310/ntj.2020.3.01
[9] CNN Indonesia. (2020). Bos Ditjen Pajak ungkap 3 dampak corona terhadap ekonomi. CNN Indonesia. Retrieved October 10, 2020 from

https://www.cnnindonesia.com/ekonomi/20 200714122341-532-524446/bos-ditjen-pajak -ungkap-3-dampak-corona-terhadap-ekon omi

[10] Ferede, W., \& Dahlby, B. (2012). The impact of tax cuts on economic growth: Evidence from the Canadian provinces. National Tax Journal, 65(3), 563-594.

https://doi.org/10.17310/ntj.2012.3.03

[11] Ghozali, I. (2006). Aplikasi analisis multivariate dengan program SPSS. (4th ed.). Semarang: Badan Penerbit Universitas Diponegoro

[12] Gujarati, D. (2003). Ekonometri dasar. Terjemahan: Sumarno Zain. Jakarta: Erlangga

[13] Gupta, A. S. (2007). Determinants of tax revenue efforts in developing countries. International Monetary Fund Working Papers, 07/184, International Monetary Fund

[14] Harahap, A. A. (2004). Paradigma baru perpajakan indonesia perspektif ekonomi-politik. Jakarta: Integrita Dinamika Press

[15] Heinemann, F. (2011). Economic crisis and morale. European Journal of Law and Economics, 32, 35-49. https://doi.org/10.1007/s10657-010-9165-z

[16] International Labour Organization. (2020). ILO monitor: COVID-19 and the world of work (2nd ed.) [Briefing note]. International Labour Organization.

https://www.ilo.org/global/topics/coronaviru s/impacts-and-responses/WCMS_740877/la ng--en/index.htm

[17] International Monetary Fund. (2009). Debt bias and other distortions: crisis-related issues in tax policy. International Monetary Fund Policy Papers. International Monetary Fund

[18] Johnson, N., Collins, C., \& Singham, A. (2010). State tax changes in response to the recession. Center on Budget and Policy Priorities.

https://www.cbpp.org/research/state-tax-ch anges-in-response-to-the-recession 
[19] Kaplanoglou, G., Rapanos, V. T., \& Daskalakis, N. (2016). Tax compliance behaviour during the crisis: the case of Greek SMEs. European Journal of Law and Economics, 42, 405-444. https://doi.org/10.1007/s10657-016-9547-y

[20] Leung, K., Wu, J. T., Liu, D., \& Leung, G. M. (2020). First-wave COVID-19 transmissibility and severity in China outside Hubei after control measures, and second-wave. The Lancet, 395(10233), 1382-1393.

https://doi.org/10.1016/S0140-6736(20)3074 6-7

[21] McKibbin, W. J., \& Fernando, R. (2020). The global macroeconomic impacts of COVID-19: seven scenarios. CAMA Working Paper No. 19/2020. SSRN.

http://dx.doi.org/10.2139/ssrn.3547729

[22] McKinsey \& Company. (2020). COVID-19: Briefing Materials Global Health \& Crisis Response. McKinsey \& Company

[23] Mittone, L. (2006). Dynamic behaviour in tax evasion: An experimental approach. Journal of Behavioral and Experimental Economics, 35(5), 813-835.

https://doi.org/10.1016/j.socec.2005.11.065

[24] Organization for Economic Co-operation and Development. (2004). Compliance risk management: Managing and improving tax compliance. Organization for Economic Co-operation and Development

[25] Organization for Economic Co-operation and Development. (2020a). Public servants and the coronavirus (COVID-19) pandemic: Emerging responses and initial recommendations. Organization for Economic Co-operation and Development

[26] Organization for Economic Co-operation and Development. (2020b). Tax administration responses to COVID-19: Recovery period planning. Organization for Economic Co-operation and Development

[27] Organization for Economic Co-operation and Development. (2020c). Tax and fiscal policy in response to the coronavirus crisis: Strengthening confidence and resilience. Organization for Economic Co-operation and Development
[28] Soto-Acosta, P. (2020). COVID-19 pandemic: Shifting digital transformation to a high-speed gear. Information Systems Management, 37(4), 260-266. https://doi.org/10.1080/10580530.2020.1814 461

[29] Torgler, B. (2013). Tax compliance and tax morale: a theoretical and empirical analysis. Monograph Book

[30] United Nations Department of Economic and Social Affairs. (2020). COVID-19: Embracing digital government during the pandemic and beyond. Policy Brief No 61. United Nations.

https://www.un.org/development/desa/dpa d/publication/un-desa-policy-brief-61-COVI D-19-embracing-digital-government-during -the-pandemic-and-beyond/

[31] World Bank. (2020). Global economic prospects. A World Bank Group Flagship Report

[32] World Health Organization. (2020). The New Normal

[33] Young, H. P. (2007). Social norms. Economics Series Working Papers, 307, University of Oxford, Department of Economics

[34] Zhao, B. (2020). Forecasting the New England States' tax revenues in the time of the COVID-19 pandemic. Current Policy Perspectives 88356. Federal Reserve Bank of Boston. 